\title{
THE NEW RATIO STUDIORUM: VICO CONTRA ARNAULD
}

\author{
Claudia Megale*
}

\begin{abstract}
Vico shares with Arnauld's Logique its being above all an Art de penser and, hence, like all arts, founded on experience, as well as reflection dedicated to the results to which they have led as determined by its ways of thinking. As regards the useful its criterion presided like an imposition. Conceiving, judging, reasoning, ordering and it was precisely on ordering that we took our time, it could accord to a method which brought into play one of the fundamental themes of Cartesian pedagogy. Another reflection is necessary on the sources so as to be able to understand how much Vico took from Arnauld, and to see how close he felt to Jansenist Logic which would then lead to such bitter delusion. The first source which intervened is Aristotle with his Analytics, a founding place for all the rules of logic. The gravest danger, for De ratione's author, came from exchanging method with reality, the rules of the mens with the metaphysics of being, to such an extent that it hindered the true turning-point of modern knowledge.
\end{abstract}

Keywords: Vico. Arnauld. Logic. Cartesian pedagogy.

\section{RIASSUNTO}

Vico condivide della Logique di Arnauld il suo essere prima di tutto Art de penser e, quindi, come tutte le arti, fondata sull'esperienza, la riflessione dedicata ai risultati a cui porta suoi modi di pensare. Per quanto riguarda l'utile suo criterio presiedette come un'imposizione. Concepire, giudicare, ragionare, ordinare ed è proprio sull'ordinare, sul procedere secondo un metodo, che entra in gioco uno dei temi fondamentali della pedagogia cartesiana. Un'altra riflessione è necessaria sulle fonti in modo da essere in grado di capire quanto Vico ha preso di Arnauld, e per vedere quanto vicino si sentiva dalla Logica giansenista che avrebbe poi condota a tale amara delusione. La prima fonte che è intervenuto è Aristotele con i suoi

\footnotetext{
* Dottoranda di Ricerca nella Università degli Studi di Napoli "Federico II". E-mail: claudia.megale@unina.it.
} 
Analtici, un luogo fondante di tutte le regole della logica. Il pericolo più grave, per l'autore del De ratione, proveniva da scambiare il metodo con la realtà, le regole della mens con la metafisica dell'essere, a tal punto che ostacolava il vero punto di svolta del sapere moderno.

Parole chiave: Vico. Arnauld. Logica. Pedagogia cartesiana.

In 1707 with the coming of the new century, the dominator changed. Naples turned over a new leaf as Charles III of Austria became the new king of the city. The cultural world was in a ferment, the political prospects of the Neapolitan civil class suffered a mighty loss in power because of the political-cultural upheaval which had been going on for a while. During these times in Naples the history of ideas felt the need to convert itself into a histrory of facts thanks above all to the hard work of prestigious jurists. This privilege was due to only two people and also regarded Vico's juridical formation. Firstly there was Carlo Antonio De Rosa who, in fact, published in 1707 the Resolutiones criminales, which dealt with penal law which was considered the true watershed between the old and the new probatory system founded on juridical torture, which opened the door for the principle of free conviction as regards the judge. The authoritative and influential magistrate cultivated the scientific and literary training for themselves by giving his support to talented young prospects. And Vico, in his Autobiography, confides that when "he wanted to apply himself to the tribunals", that it was Carlo Antonio De Rosa, "the senator of the highest integrity and protector of his house", who sent him to the legal studio of an old and esteemed advocate, Fabrizio del Vecchio ${ }^{1}$.

Also in 1707 Nicola Caravita who was Professor of Feudal Law at the University of Naples, as well as a friend and protector of the Neapolitan philosopher, intervened and made sure that he obtained

Vita di Giambattista Vico scritta da sé medesimo (1723-1728), in G. Vico, Opere, edited by A. Battistini, Milan, Mondadori, 1990, t. I, p.10 (see now G. Vico, Vita scritta da se medesimo, introduction by F. Lomonaco, afterword by R. Diana and bibliography by S. Principe, Naples, Diogene, 2012). 
the Chair of Rhetoric and was also welcomed into the Accademia Palatina, wrote a treatise (Nullum ius romani pontificis in Regnum neapolitanum) against the feudal pretensions of the Holy See in the Kingdom of Naples.

This was the climate that prevailed when Professor Vico was asked to give the inaugural oration for the academic year in 1708. It was published and was entitled De nostri temporis studiorum ratione in 1709. As with all Vico's work when examined closely we see that it is somewhat composite and can be interpreted at various levels. It is certain that as this is an inaugural oration, its main object was to speak to the young students in the University who were exhorted to cultivate modern knowledge and to try to find unity there so as to feed their civil conscience as the phenomenon of neofeudalization had conditioned them by driving them in the opposite direction from what was practised by Neapolitan jurists.

In his 'oratory' undertaking there can be seen the search for political judgement, assisted by the theory of the motives of equity in its two forms, i.e. the natural and the civil ones. These were necessary to re-new the judicial activity. This theme was central to De uno where he dealt with the distinction between usefulness as an "occasion" and honestas as a "reason" of law ${ }^{2}$.

Wishing to concentrate in one single expression a level of reading to be deepened, we would talk about Vico's proposal as a new cogito, i.e. the mind as an activity and an invention. It did not reveal the ways of the world but tried to understand its sense, opposing necessity with the probable way so as to contribute to a new science founded on what was "likely" against the presumed absoluteness of scientific propositions. The re-valuing of the "probable" was fundamental for the formation and activity of the mens, ensuring there was an alternative to the Cartesian model of reason. The relationship with the verum was arrived at by discovering the "true seconds, or

2 G. Vico, De universi iuris uno principio, et fine uno (...), Neapoli, F. Mosca, 1720, reprint by F. Lomonaco, preface by F. Tessitore, Naples, Liguori, 2007. italian traduction in Id., Opere giuridiche, edited by P. Cristofolini, introduction by N. Badaloni, Florence, Sansoni, 1974, p. 60. 
the likely ones", of knowledge, i.e. 'in the middle' between truth and falseness, the object of the topic. His critical method was substituted by the topic, "art in the fertile oration" to which was entrusted the upbringing of young people. But Vico also intended to link its meaning to the "doctrina moralis civilisque". He gave credit to a model of knowledge which did not involve the single person but men in that they were social beings, artificers of social life. The did not mean considering the topic as an alternative to criticism, as much as discussing again, as regards the origins of the educational process the primacy of the 'machines'. This had to be joined to a learning that, through an inventive moment, was prepared for the critical activity, so the "topic as a taught subject must precede the criticism"3. The new nucleus of the activity of reason became an inventio, an activity with a competence talent. "All the dissertation is the defence of a method which does not reach a rational demonstration, at the conclusions of judgement and criticism but only after the collection and the dispositio of the subjects in accordance with the unforeseeable real activity", he wrote emphatically ${ }^{4}$. To follow up such a methodological plan Vico set out from his writer, Bacon, and from something he wrote in 1623, De dignitate et de augmentis scientiarum which was used to culturally motivate his design for unifying the knowledge of contemporary man. Wishing to compare the methods of the ancients and modern ones meant not only introducing a new method into his well-known fundamental articulations (instruments, subsidies and a goal) but there was also the choice of cultural models. These were Bacon's and the Anglo-Saxon culture which were alternatives to the lesson of the French and, in primis, Descartes's and the Cartesian one.

This brought into play the Cartesian criterion of clear and distinct truth brought into discussion by a different, renewed metaphysics

3 G. Vico, De nostri temporis studiorum ratione dissertatio (...), Neapoli, Typis Felicis Mosca, 1709, reprinted with introduction by F. Lomonaco, Naples, Scripta Web, 2010, p. 71 (hereafter with De ratione). For an up-to-date information see p. $7 \mathrm{ff}$.

4 De ratione, p. 13. 
of the mens which no longer used the analytical procedure, because it entered into the sphere of modern geometry. The synthetic one of the ancients was able to reproduce the creative act at the origin of the world in the shape of intuitive construction and following a procedural affinity in an ingenious way. Topic and geometry could, therefore, flow together into a new study of mathematics, the real watershed between Vico and his Cartesian contemporaries.

Mathematics was particularly studied in Naples at the beginning of the eighteenth century. It was the subject of scientific debates in various circles and academies. We must remember, in particular, Agostino Ariani's lessons in the Accademia Palatina. The scholar defined geometry as "pure science" in that it is based not only on extraordinary cognitive functions, but it also has a pedagogic value, and this was the reason why it was central to the re-neved, philosophical historiography which wanted to define the characters of Neapolitan Cartesianism in the seventeenth and eighteenth centuries ${ }^{5}$.

The idea to use this very noble discipline leads to its principles being more taken up and put down again, and from every particular, which it takes into consideration, it takes from it the nature of its reasons, I will say it is a science also because it considers very closely its subjects and teaches us to know the truth and gives us the means to re-find it and show it perfectly. Thus this is geometry's main usefulness, and it helps to perfect the mind, or reason, which when used correctly all the other sciences and all the discourses and all human doings depend on it, as Ariani wrote ${ }^{6}$.

We must underline that such an observation constitutes an interesting paraphrase for some pages in Pierre Nicole's Préface to the Nouveaux éléments de géometrie by Arnauld. The picking out of this

5 On this theme see E. Nuzzo, Verso la "Vita Civile" Antropologia e politica nelle lezioni accademiche di Gregorio Caloprese e Paolo Mattia Doria, Naples, Guida,1984, p. 212ff.

6 A. Ariani, Intorno all'utilità della geometria, in M. Donzelli, Natura e humanitas nel giovane Vico, Naples, Istituto italiano per gli studi storici, 1970, p. 166. 
source points out above all the presence in Naples of a fundamental component of European Cartesianism, and confirms, if there were any more need for it, his unsuccessful isolation and Vico's backwardness in his time, as Enrico Nuzzo's studies have documented ${ }^{7}$. In particular Ariani with his intervention contributed to testifying that, in certain environments of southern Cartesian culture, Arnauld's deductivism, more or less without its most important religious connotations, was practised, or noticed - as it was by Vico - in a still more rigid form than its original one. Not only this, but Ariani praised enthusiastically the cognitive and pedagogic capacities of this most sensitive form of geometry as used by Malebranche in respect to the greatest representatives of Jansenism from the 1750's onwards ${ }^{8}$. Arnauld himself had an epistolary exchange on many different subjects with the author of La Recherche de la vérité.

The new ratio studiorum proposed that on a pedagogical level it took on the knowledge of the social usefulness of the science, bound to the function of common sense. "The appreciation of this modern scientific method is not brought into doubt, but what Vico refuses is the new criticism, or even better still the new logic which is pre-supposed as a condition of the mechanism itself. This new logic whose representative is symbolized by Arnauld, reduces everything to a deductive procedure, it scorns the likelihood of not following the chain of examples" as Nicola Badaloni well pointed out ${ }^{10}$. I will take

7 E. Nuzzo, Verso la "Vita Civile” Antropologia e politica nelle lezioni accademiche di Gregorio Caloprese e Paolo Mattia Doria, p. 212-216.

8 E. Nuzzo, Verso la "Vita Civile” Antropologia e politica nelle lezioni accademiche di Gregorio Caloprese e Paolo Mattia Doria, p. 213.

9 Arnauld - observed Senofonte - "lesse con molto interesse l'opera di Malebranche e dall'uso che ne faceva si potrebbe sospettare che questa lettura lo abbia molto aiutato a guardare Cartesio sotto la particolare prospettiva di un autore che avesse scritto specificamente allo scopo di difendere la fede cristiana" (C. Senofonte, Ragione moderna e teologia. L'uomo di Arnauld, Naples, Guida editori, 1989, p. 221).

10 So N. Badaloni, Introduzione a Giambattista Vico, Milan, Feltrinelli,1961, p. 329. On the Logique in the Neapolitan context see S. Serrapica, Discussioni di logica nella Napoli di Vico, in Il mondo di Vico/Vico nel mondo. In ricordo di Giorgio Tagliacozzo, edited by F. Ratto, Perugia, Guerra, 2000, p. 231-242. 
this judgement as a starting point, to emphasize, in analyzing Chapter III of De ratione, the reasons which induced Vico to cite Arnauld and, then in general, to re-act against the evolution of Cartesianism in the logical-mathematical rigorism of the Jansenists of Port-Royal. La logique was written in collaboration with Pierre Nicole in 1662. It was also called Art de penser, art which in a sense remembered that of the Greek téchne. The work is divided into four parts. The first regards the idea, or mental conceiving. The second introduces itself as "a reflection that men have made on their judgements" 11 and is dedicated to the structure of these propositions and to complex propositions. The third talks about syllogisms and wrong reasonings called sophisms. The fourth is significant enough for its critical comparison of Vico, with regard to his method and helps to set out the path to follow to build up the sciences, and in particular geometry.

The Neapolitan philosopher could not but compare himself with the general objectives of the logic of Port-Royal that proposed itself with a series of theses common to the Cartesians. The first of all the capacities was to discern truth from falsehood: "We use reasoning as an instrument to acquire sciences. We should instead use sciences as an instrument to perfect reason, in that common sense of the mind is infinitely more esteemed for all its speculative knowledge, which we can arrive at with the help of truer and more solid sciences" 12 . The speculative sciences "are completely useless if you take them for what they are. Man was not put on this earth to waste his time in measuring lives, examining the relationships between angles, in considering the different movements of the subject. Their spirit is too big, their life too short, their time too precious to think about such trifles. Instead they are busy with being right, equanimous, able to judge in all their talk, in all their actions, in all their dayto-day business. They must try to form themselves in this way, in

11 Cf. L. Verga, Il pensiero filosofico e scientifico di Antoine Arnauld, Milan, Vita e Pensiero, 1972, Book I, p. 278.

12 A. Arnauld; - P. Nicole, La Logique ou l'Art de penser, in Oeuvres, Paris, D'Arnay, 1775-1781, t. XLI, p. 15. 
particular"13. And in the De ratione itself Vico re-proposed a difference which was very similar with regard to man's speculative sciences:

The first thing that is found in adolescents is common sense, until they arrive, through maturity, to when they put it into practice, they do not break out into strange and unusual actions. Common sense is generated from likelihood as science is generated from truth and error from falsehood. And in effect this likelihood is similar to an intermediary between truth and falsehood, as being for the most part true, rarely enough is it false ${ }^{14}$.

The Neapolitan philosopher shares with Logique its being above all an Art de penser and, hence, like all arts, founded on experience, as well as reflection dedicated to the results to which they have led as determined by its ways of thinking. As regards the useful its criterion presided like an imposition. Arnauld and Nicole were not of the idea - in common with Descartes - that logic could be reduced to a dialectic, or to the rules which concern right deduction. The latter could only be the result of the most important part, to not limit itself to only reasonings instead of taking into consideration every form of thought, in other words, an Art de penser. Conceiving, judging, reasoning. ordering and it was precisely on ordering that we took our time, it could accord to a method which brought into play one of the fundamental themes of Cartesian pedagogy, which was efficient also in documenting the resistences to logic teachings from the 1750's onwards in Europe ${ }^{15}$.

\footnotetext{
13 L. Verga, Il pensiero filosofico e scientifico di Antoine Arnauld, p. 169.

14 De ratione, p. 67.

15 "L'esperienza - Verga observed - ci dice che di mille giovani che imparano la Logica, non ce ne sono dieci che ne sappiano qualche cosa sei mesi dopo che hanno terminato il corso. Cosa c'è di più scoraggiante nel vedere quanto ancora fanno gli alunni dei corsi di Logica i quali si abituano a rinchiudere la logica nella Logica, senza portarla oltre, mentre essa non è fatta che per servire di strumento alle altre scienze. Si ha così che, non avendone mai visto il vero uso, non la mettono neppure in pratica, anzi sono ben contenti di sbarazzarsene come di un sapere infimo e inutile" (L. Verga, Il pensiero filosofico e scientifico di Antoine Arnauld, p. 186).
} 
Another reflection is necessary on the sources so as to be able to understand how much Vico took from Arnauld, and to see how close he felt to Jansenist Logic which would then lead to such bitter delusion. The first source which intervened is Aristotle with his Analytics, a founding place for all the rules of logic. The gravest danger, for De ratione's author, came from exchanging method with reality, the rules of the mens with the metaphysics of being, to such an extent that it hindered the true turning-point of modern knowledge. This was because Vico observed in his Autobiography: "Arnauld works his (metaphysics) on the plan of Aristotle's"16. And Verga astutely wrote "this notwithstanding the lack of faith he declared for the formal part of Aristotle's logic, that then obtains an ample enough discussion in the Logique. This is notwithstanding having evidenced frequently enough in the work errors and insufficiencies met in Aristotle's philosophy. It is very far from harming Aristotle's value as a logician, it explains the shortcomings because precisely he has no faith in the established rules of logic ${ }^{17}$. Descartes is the second author to whom Arnauld and Nicole have recourse above all with regard to the evidence of clear and distinct ideas and their methods in the two moments of analysis and synthesis. They come into play in Part II of Discours de la méthode read bearing in mind Regulae and the first part of Principia Philosophiae.

What Arnauld proposed to do in the third part of the Logique was to illustrate the different ways for the rules of reasoning. This is what he judged the most important place of logic, even if stating that most human errors came from the fact they were based on false principles:

The part that we must deal with now, and this includes the rules of reasoning, is considered the most important of Logic, and it is almost the only one that is dealt with carefully in any way. But there is reason to doubt that it is as useful as it is thought to be. Most errors by men (...) happen more because they reason

16 Vita di Giambattista Vico scritta da me medesimo, p. 22.

17 L. Verga, Il pensiero filosofico e scientifico di Antoine Arnauld, p. 188. 
using false principles rather than because they reason, following badly, false principles ${ }^{18}$.

It is important to underline that these observations on bad human understanding as regards the meaning of words, were already shown by Arnauld in Jansenian Catechisms in defending free will ${ }^{19}$. Arguing like this was founded on man's limits, when asked to judge between the truth and falsehood of a proposition:

The necessity for reasoning is founded on the restricted limit of the human spirit which, when having to judge on the truth or falsehood of a proposition (which is then called question), cannot always do it through considering the two ideas which make it up. Then that which is the subject is called also a small term, in that it is usual that the subject is less extended than the attribute, and then there is the attribute which is also called big term for the opposite reason. So when the only consideration of these two ideas is not enough to allow judgement, then you need to affirm or deny one or the other, you have recourse to a third idea, whether it is complex or not (...), which is called medium ${ }^{20}$.

Man's limits, his integrity to know the truth in an immediate form, were the pre-suppositions of freedom itself. This is because the capacity to decide on the truth or falsehood of a proposition were in play. The Cartesian cogito, self-conscience in as much as it was of the pure capacity of thought, was, in Logique, re-affirmed as a universal characteristic of man. In his capacity to think he expressed himself, comparing a small term, a big one or another medium one and he was totally free to operate. It is conscience which allowed us to judge if a proposition was true or false. Now such a conscience could

18 A. Arnauld, Grammatica e Logica di Port-Royal, edited by R. Simone, Rome, Ubaldini, 1969, p. 232.

19 A. Arnauld., Catechismi giansenisti, edited by G. Morra, Forlì, edizioni di Ethica, 1968, Chap. III, p. 40.

20 A. Arnauld, Grammatica e Logica di Port-Royal, p. 232-233. 
happen in two ways: either directly or because it was guaranteed by an authority which was worthy of credit:

In fact, because of two general ways we believe that something is true. The first is the knowledge that they are there for us, because of having recognized and searched for the truth both by our senses and reason. That can generally be called reason, in as much as the senses depend on the judgement of reason. There is also science, using this name in a more general sense than it is used in schools, to indicate every knowledge of an object drawn from the object itself. The other way is the authority of people worthy of credit, who assure us that such a thing is, even if properly speaking we know nothing about it. This is called faith, or belief $(\ldots)^{21}$.

As regards the relationships between faith and reason, Arnauld dedicated the fourth part of his Logique to it. From the very start he distinguished between the two types of faith, i.e. in God and man. "Human faith is by its very own saying so subject to error, because every man is a liar, according to the Scriptures, and perhaps assures us that something is true if he himself is tricked. And however (...) there are things we know only through human faith, and that we must consider certain and indubitable as if we had the mathematic demonstration of them (...)"22.

Thus there came about the proposal to reconciliate Cartesian philosophy with Agostinian theology, to safeguard free will without placing limits on God being all-powerful, but showing those where there was the capacity to reason. This was an essential condition for a human being. This explained the double, contrasting interest which Vico had for Arnauld's theses which involves common sources, like Augustine, reconciled in the four Objections to the Metaphysical Meditations with their author as regards well-known and complicated subjects, i.e. the separation between soul and body, the existence of

21 A. Arnauld, Grammatica e Logica di Port-Royal, p. 374.

22 Ibid. 
God as a causa sui, and his theories on desire and free will. The latter was the proof of indisputable certainty and was the knowledge of very existence itself. Re-reading Descartes from an Agostinian point of view means taking away from philosophy attempts at identifying it with religious heresy and re-valuing from that philosophy the argumentation method. Senofonte wrote: "As regards Descartes Arnauld appreciated above all his clear reasoning, his short discourse, his succinct exposition, his abstention from using analogies and uncertain conjecture and his concern with always trying to base everything on clear and certain principles"23.

Vico's interest in Augustine was diversified enough in the course of his technical experience and he tried to impoverish the presumed absoluteness of cogitating on these arms themselves (Agostinian) that demonstrated an intelligence which was the knowledge of a true inwardness of man whose divine force was lived in the world through abstract, transcending safety ${ }^{24}$. In short an internal reform as regards cogitating and to be understood not as a pure thought but as a remembering power, rich in images and figures, communicating with the body, so that with the body entering into play there is the fear that fuses the reaction of the mens-corpo to the lightning, a symbol of the sky and of divine power for modern man.

Going back to the conciliatory prospective of Arnauld's logic, it is necessary, then, to individualize in geometry and mathematics the ideal fields to apply this logic in. Therefore, when in Chapter III of Part IV of Logique, he dealt with the synthetic model which was adequate for the demonstration of truth, he affirmed that the way followed by geometricians was the most adapt to illustrate it. This was because they have not left anything obscure in the terms in which they are used and they did only depart from clear and evident principles and showed all the conclusions reached. The fourth part of Logique tried to show without leaving any doubt the general rules

23 So C. Senofonte, Ragione moderna e teologia. L'uomo di Arnauld, p. 199.

24 On the theme M. Sanna, Dallo scire al conscire: un moderno itinerario cognitivo, in «Bollettino del Centro studi vichiani» XL (2010),, 1, expecially p. 85-86. 
to lead forward reason in believing in those events which depended on human faith and in a relationship and that there were two distinct types of freedom:

The first reflection is that you need to distinguish very carefully between two types of truth: the former concern only the nature of things and their unchangeable essence, regardless of their existence. The latter concern existing things, above all human and contingent events, that can be and not be when you talk about the future, and could have been and not have been, when you talk about the past. I mean all that according to its next causes, making an abstraction of unchangeable order that these things have in the providence of God, since on the one hand he does not hinder their contingency, and on the other, as it is not wellknown, he does not contribute in any way to make us believe these things ${ }^{25}$.

Here there returned that notion (of contingency) that Arnauld defended in correspondence with Leibniz. Divine omniscience and providence itself did not deprive events of their effectiveness and the fact that we totally ignore what is the divine design is the guarantee of our possibility of believing or not in things. "In fact as regards these events because of their contingent nature, it would be ridiculous to search for a reasoning truth there. Hence a man would be totally unreasonable if he wanted to believe it only when he was made to see that it is absolutely necessary that the thing happened in that way"26. The general rule to judge a fact was to consider all the circumstances that accompany it, only in this way was man capable of deciding whether or not to believe in something, i.e. "to judge the truth of an event, and to determine whether or not to believe in it, you do not need to consider it as a bare fact and in itself, as we would do with a Geometry proposition, but you need to pay attention to all these

\footnotetext{
${ }^{25}$ A. Arnauld, Grammatica e Logica di Port-Royal, p. 377.

${ }^{26}$ Ibid
} 
circumstances which accompany it, both internal and external" ${ }^{\prime 2}$. This rule was the criterion for truth and was applicable in whatever case you could think of, even for extraordinary events like miracles.

L'Art de penser for Arnauld that "it is difficult to understand" 28 was more deluding than Cartesian logic and Vico recognized its merit of having founded criticism. Even though he knew that geometry was made up of a different procedure than the analytical one, Arnauld "is not however able to see clearly into what is rightly geometry, because he is a prisoner of the Aristotelian-scholastic scheme of the passage from race to species. In reality this passage involves following in an inverse sense an abstractive procedure and hence for himself it is not at all the means which provide the explanation for all sciences" ${ }^{29}$. As regards Vico Arnauld kept geometry in the field of non-productive imagination but as a source of illusions. When the Cartesian Jansenist sustained, for example, that it was contained in the clear and distinct idea of a triangle that there were three sides, and that the sides were three and only three it could be affirmed as a truth of the triangle and not the idea of the triangle. It was, in fact, the triangle that had the three sides, not its idea. As regards Vico such confusion between the idea and the thing showed the critical weakness in distinguishing between the reference levels. He assigned to geometry a pedagogical function with its notable importance but this was unthinkable for Arnauld. Creative capacity, "re-finding new things" was the prerogative of the talent that was kept working while exercising with geometry which "cohibet ingenia dum discitur, quo, dum ad usum revocetur, peracuat" $"$.

It is interesting to note the use that Vico gave to the verb acuo (in which per which precedes the verb is translated by continually and right to the end) differently from the verb cohibet, which indicates geometry when it is learnt theoretically and which puts a brake on talents (cohibet) to then make them go both insightfully and

\footnotetext{
27 A. Arnauld, Grammatica e Logica di Port-Royal, p. 378.

28 De ratione, p. 85.

29 C. Senofonte, Ragione moderna e teologia. L'uomo di Arnauld, p. 300.

30 De ratione, p. 98.
} 
continually right to the end (peracuat) when discipline is re-called to its applicative duties. As regards Arnauld, instead, all the knowledge is reached and organized through the use of two fundamental methods, i.e. that of analysis, called also resolution or invention, and that of synthesis of composition or of doctrine. Notwithstanding the fact he retained the latter superior to the former under an exclusively Cartesian character, when he cited the procedures of geometry as an example of a method of composition he proceed with good examples but "he does not link it to the idea of procedure from race to species but rather to the operative and combining procedure" 31 . Here were the reasons why Vico concluded Chapter III of De ratione with the affirmation of the paradoxical but significant correspondence on the Arnauldian method with the Aristotelian lesson, then he continued with metaphysics and Descartes's method:

Arnauld himself, although he refuses this method of study verbally, in practice he adopts it, filling up the logic of many inmost recesses (...). These examples, if the arts and sciences from which they are deduced are not learned beforehand, the listener will struggle to understand them (...). Therefore if logic is learned at the end, over and above what was said above, also those inconveniences are avoided. Arnauld's, although he gave useful examples, are difficult to understand and the Aristotelian ones, although they are understood, are in no way useful ${ }^{32}$.

\section{References}

ARNAULD, A. Catechismi giansenisti. Edited by G. Morra. Forlì: Edizioni di Ethica, 1968.

. Grammatica e Logica di Port-Royal. Edited by R. Simone. Rome:

Ubaldini, 1969.

; NICOLE, P. La Logique ou l'Art de penser. In: . Oeuvres. Paris: D'Arnay, 1775-1781.

31 So C. Senofonte, Ragione moderna e teologia. L'uomo di Arnauld, p. 300.

32 De ratione, p. 85. 
ARIANI, A. Intorno all'utilità della geometria. In: DONZELLI, M., Natura e humanitas nel giovane Vico. Naples: Istituto italiano per gli studi storici, 1970.

BADALONI, N. Introduzione a Giambattista Vico. Milan: Feltrinelli, 1961.

NUZZO, E. Verso la "Vita Civile” Antropologia e politica nelle lezioni accademiche di Gregorio Caloprese e Paolo Mattia Doria. Naples: Guida, 1984.

SANNA, M. Dallo scire al conscire: un moderno itinerario cognitivo. Bollettino del Centro studi vichiani, XL (2010), 1.

SENOFONTE, C. Ragione moderna e teologia. L'uomo di Arnauld. Naples: Guida editori, 1989.

SERRAPICA, S. Discussioni di logica nella Napoli di Vico. Il mondo di Vico/Vico nel mondo. In ricordo di Giorgio Tagliacozzo. Edited by F. Ratto. Perugia: Guerra, 2000.

VERGA, L. Il pensiero filosofico e scientifico di Antoine Arnauld. Milan: Vita e Pensiero, 1972. Book I.

VICO, G. De nostri temporis studiorum ratione. Neapoli: Typis Felicis Mosca. Reprinted with introduction by F. Lomonaco. Naples: Scripta Web, 2010.

. De universi iuris uno principio, et fine uno. Neapoli: F. Mosca, 1720. Reprint by F. Lomonaco. Preface by F. Tessitore. Naples: Liguori, 2007.

. Opere giuridiche. Edited by P. Cristofolini. Introduction by N. Badaloni. Florence: Sansoni, 1974.

. Vita di Giambattista Vico scritta da sé medesimo (1723-1728). In:

VICO, G. Opere. Edited by A. Battistini. Milan: Mondadori, 1990.

. Vita scritta da se medesimo. Introduction by F. Lomonaco, afterword by R. Diana and bibliography by S. Principe. Naples: Diogene, 2012.

Data de registro: $17 / 06 / 2013$

Data de aceite: 22/01/2014 